\title{
Organic Fertilizers Vis-à-vis Growth Performance of Euphorbia fulgens
}

\author{
Florita O. Odivilas, PhD \\ Eastern Samar State University, Salcedo Campus \\ Salcedo, Eastern Samar, Philippines
}

doi: 10.19044/esj.2016.v12n18p24 URL:http://dx.doi.org/10.19044/esj.2016.v12n18p24

\begin{abstract}
This study was conducted to find out the effect of fertilizers on the performance of two hybrids of Euphorbia as indicated by growth and flowering performance. The experimental design with controlled variables was used in the study. The use of organic fertilizers like the use of animal dungs or wastes was proven effective based on the different trials made. In terms of the effect of the fertilizers in the growth performance, there were significant differences on plant height, stem girth, number of leaves, and number of shoots during the $20^{\text {th }}, 50^{\text {th }}$ and $80^{\text {th }}$ days of observations. The number of flowers was found to have significant differences in all stages. When measured during the $80^{\text {th }}$ day of observation, significant differences were shown in the size of flowers. However, insignificant difference was shown in the diameter of flower bracts. As to the growth parameters, carabao manure yielded more leaves, and shoots and taller Euphorbia Orchid. It also produced bigger stem girths, wider and longer leaf sizes of Siam Ruby hybrid. As to flowering parameters, carabao manure influenced the growth of more number of flower clusters and bigger sizes of flowers of Euphorbia Orchid. On the other hand, chicken manure also influenced the growth of more number of flowers per cluster of Siam Ruby during the $50^{\text {th }}$ day observation and carabao manure during the $20^{\text {th }}$ day observation.
\end{abstract}

Keywords: Organic fertilizers, growth and flowering parameters, horticulture-based materials

\section{Introduction}

One of the most admired potted flowering plants today is euphorbia, scientifically known as "Euphorbia fulgens", commonly dubbed as "Crown of Thorns", because of its thorny stem. This specie can be grown chiefly by cuttings, which captures great interest in floral blooms in a mosaic of colors that makes it unusual compared to other varieties. Around 20 varieties of this 
specie belong to the family Euphobiaceae. It is woody, spiny, and climbing shrub. The leaves are evident mostly on young growth, and have small bracts of pink or red flowers (Larson, 1992).

The demand for Euphorbia as a potted ornamental and a landscape material has drawn problems to plant enthusiasts particularly in supplying buyers in the Philippines. In Region VIII alone, varieties have to be purchased from Davao City or Manila and be distributed in the provinces of Eastern Visayas. Middlemen from Mindanao on the other hand, order Euphorbia cuttings from Thailand through contacts which entail much transportation cost to the buyer-growers. Many local raisers attempt to produce varieties by way of cuttings; while others focus on production of new plants through seeds. But, while the production of new plants through cuttings was considered the easiest method, only a very limited percentage survives. On the other hand, euphorbia reproduction by seeds takes months to germinate with relatively low percentage of survival (Carola, 2009).

In order to enhance production, attempts are also made by flower growers in the region by utilizing various fertilizers. One of the common fertilizers is the complete commercial fertilizer. This is a combination of nitrogen, phosphorous and potassium (NPK). However, local growers experience that such fertilizer material makes growing media more compact and the soil requires constant fertilizer application. The utilization of organic fertilizers is studied in agronomic and horticultural plants. These are utilized because of its high nutrient content, availability and low cost (Lantican, 2001). In the locality, organic fertilizers are also utilized but acceptable results are yet to be tested and documented, hence this study is intentionally conducted.

\section{Literature of the Study}

It is said that plants in the garden remove life's stresses, more especially on botanical gardens that provide a perfect bloom during the season. Maintaining a healthy and well-maintained garden is always a challenge among garden enthusiasts. Thus, different mechanisms are observed in order to provide the blooming cycles of botanical gardens more possible.

The study of Kone, Yte, Sekou, Konan, Koutou, Konan, \& Zouzou (2014) emphasize the use of dry cow dung (cattle waste), which increases relative nitrogen, phosphorus, potassium, and magnesium contents that contribute to soil fertility and potential vegetative growth of $30 \%$. Inocian and Nuñeza (2015) support the use of organic fertilizers in the production of vegetable garden in Talamban Elementary School. Carbonell (2015) emphasizes the growing interest in the use of organic fertilizers because this 
can increase demand for organically grown products and provide balance of soil contents.

Old Euphorbia fulgens are more productive compared than the young when exposed to different treatments like periods and temperatures (Farina, 1983). This means that the old breed is ideal for plant propagation with corresponding regulation and timing in terms of location, period, and weather conditions like temperature, humidity, and sunlight. To Runger and Albert (1975), the higher temperature impacts the growth of the euphorbia when measured with the difference between moist and dry soil. As a desert plant, euphorbia needs to be exposed in warm temperature with a very little water (Interflora, n.d.).

These literatures provide the public attention on the use of organic fertilizers to protect the environment from soil acidity brought by the use of commercial fertilizers, and to maintain a stress free life brought by abundant flower blooms of the Euphorbia fulgens. And lastly, the resulting propagation may increase the standard of living among flower growers in Eastern Samar, and continuously live a sustainable life, as a way of reducing poverty in the region.

\section{Objectives of the Study}

This study analyzed the use of organic fertilizers vis-à-vis growth performance of Euphorbia fulgens. It aimed to: (1) determine the effects of fertilizers on the performance of two hybrids of Euphorbia as indicated by its growth performance and flowering performance (2) compare the performance of two organic fertilizers as applied to Euphorbia hybrids, and (3) recommend strategies in developing instructional materials in college teaching.

\section{Methods and Materials \\ Research Design}

A Complete Randomized Design (CRD) was employed in this study. The design is the most appropriate for experiments with homogenous experimental units. It is especially suited for experiments where environmental effects are easily controlled (Gomez and Gomez, 1984). The experimental area of the study is located at Sathea's Garden, Eastern Samar State University-Salcedo campus, Salcedo, Eastern Samar. The experimental plants were distributed to the assigned treatments namely: $T_{1}$ (chicken manure), $\mathrm{T}_{2}$ (carabao manure), and $\mathrm{T}_{3}$ (complete fertilizer). These were laid on the three experimental tables, where each table, represents a number of replications utilized in the study of one meter allay way was provided for each experimental table. The total experimental area reached a total of 24 square meters. 


\section{Research Tools}

This study made use of young growing Euphorbia cuttings of Siam Ruby and Euphorbia Orchid hybrids, which were chosen from reputable dealers in Davao City. The choice of these hybrids was based on two considerations: the availability of the planting materials at the time these were needed, and the hybrids being classified as "rare". Discriminate selection was done on the number, size and physical characteristics of leaves, height and stem girth as well as pest and disease indicators. A kind of growing medium composed of garden soil and rice hulls were thoroughly mixed. All pots were filled with one kilogram of growing medium with carabao and chicken manures were the organic fertilizers used in the experiment. They were air dried, pulverized and sterilized before measured and mixed with the growing medium. The Two-Way Analysis of Variance (ANOVA) was used to determine the significant differences among the variables in determining the growth and flowering performance of Euphorbia hybrids. The data were computed and analyzed using computer software program. Computations of means were also facilitated in identifying the mean values of the parameters in the study.

\section{Experiment Control}

The chicken manure, as organic fertilizers, were utilized and classified as controlled pots. Fertilizer sterilization was done through heat method where the fertilizers were uniformly leveled to accomplish equal heat distribution. Chicken manure was applied at the rate of one half kilogram per treatment while carabao manure was fertilized at the rate of $1 \mathrm{~kg}$. This ratio was adopted based on the chemical analysis published by PCARRD (1983) which showed that carabao manure has $1.22 \%$ nitrogen, $0.5 \%$ phosphorus, and $0.79 \%$ potassium. Euphorbia plants classified as control were fertilized with three tablespoons each of complete fertilizer and were divided into three applications every fifteen days after the start of the experiment. The rate of application was one tablespoon per plant per treatment. A commercially prepared fungicide was sprayed to ward off fungus attack in the control and experimental plants. Three tablespoons of Dithane were mixed with three gallons of water every spraying schedule which was done on a three-week interval during the entire experimental study.

\section{Data collection}

Growth parameters of Euphorbia were considered as follows: number of leaves, number of shoots, plant height, and stem girth. A number of leaves per test plant were counted periodically at $20^{\text {th }}$, 50th and $80^{\text {th }}$ days from planting. A number of shoots per test plant were counted following the interval of days identified from planting. A number of shoots were counted 
starting from bud formation to full shoot development. This was determined by measuring the plant from the basal portion to the crown at the specified interval or period. All test plants were identified with areas to measure stem girth and were made as reference during all measurement periods following the interval. Flowering indicators include: number of flower clusters, number of flowers per cluster, diameter of flower bracts, and size of flower. The number of flower clusters was counted at specified days of interval. The number of flowers per cluster was also counted following the counting days interval. This was measured on the $80^{\text {th }}$ day of the experiment. Measurement started with the centermost part of the flower towards the tip of the petal. This was measured during the $80^{\text {th }}$ day of the experiment. This was done by measuring the cross section of the two opposite petals starting at the tip of the petal moving towards the opposite end.

\section{Results and discussion Growth Performance Plant Height}

Euphorbia Orchid has consistently obtained a higher mean compared to Siam Ruby at different stages when fertilized with carabao manure. It is noted that complete fertilizer does not contribute much to plant height because of leaching. It is assumed that since frequent watering is done to fully saturate the soil media, greater amount of fertilizer has percolated thereby contributing lesser effect to the test plant. This observation conforms to the work of Brady (1996). He claims that inorganic fertilizer tends to be easily leached when high saturation of water is present in the growing medium. With reference to variety, it showed significant difference during the last two stages of observation.

\section{Stem Girth}

Siam Ruby yields bigger stem girth than the Euphorbia hybrid, at all stages of observation when fertilized with carabao manure. Similarly, in terms of variety variable, it shows significant difference during the last two observation periods.

\section{Number of Leaves}

Euphorbia Orchid exhibits to have better performance than Siam Ruby in terms of number of leaves when fertilized with carabao manure during the $20^{\text {th }}$ and $50^{\text {th }}$ day of observation. However, more leaves are shown during the $80^{\text {th }}$ observation in treatments fertilized with chicken manure. Result may have attributed by the higher content of Nitrogen in chicken manure (PCARRD, 1983). Treatment, as a variable, shows significant difference only in the last two stages of observation. With regard to variety 
as a variable, it shows to have significant difference in all stages of observation.

\section{Number of Shoots}

Euphorbia Orchid shows to have more number of shoots compared to Siam Ruby in all stages of observation. It may be interesting to note that at $80^{\text {th }}$ days of observation, the number of shoots has decreased. This is attributed at the start of flower-bearing where more food elements are required thus limiting more shoot growth. As to treatment variable, it shows to be insignificant. Likewise, variety as a variable yields significant difference among the hybrids.

\section{Size of Leaves}

As to width of the leaves, Siam Ruby exhibited wider leaves compared to Euphorbia Orchid when fertilized with chicken manure. This conform with the study of PhilRice (2002) and PCARRD (1983) which claim that agronomic crops like rice tend to increase the development of leaf area when sufficient potassium is available for plant growth. Further, Catuday (1980) claimed that when chicken dung was applied to peanut, all plots in his experiment established significant difference as to foliage size formation compared to control. As to length of leaves, Euphorbia Orchid also showed longer leaves compared to Siam Ruby. As to treatment variable, the result showed significant difference. However, variety proved to have no significant difference in the study.

\begin{tabular}{|c|c|c|c|c|c|c|}
\hline Source of Variation & $\begin{array}{l}\text { Sum of } \\
\text { Squares }\end{array}$ & $\mathrm{df}$ & $\begin{array}{l}\text { Mean } \\
\text { Square }\end{array}$ & $\mathrm{F}$ & $\mathrm{p}$ & Interpretation \\
\hline & & & ant Heigh & & & \\
\hline At twenty days & & & & & & \\
\hline Main Effects & 5.412 & 3 & 1.804 & .8 .034 & .000 & Significant \\
\hline Treatment & 4.978 & 2 & 2.489 & 11.084 & .000 & Significant \\
\hline Variety & .434 & 1 & .434 & 1.933 & .168 & Not Significant \\
\hline At fifty days & & & & & & \\
\hline Main Effects & 30.379 & 3 & 10.126 & 33.813 & .000 & Significant \\
\hline Treatment & 16.690 & 2 & 8.345 & 27.865 & .008 & Significant \\
\hline Variety & 13.689 & 1 & 13.689 & 45.71 & .000 & Significant \\
\hline At eighty days & & & & & & \\
\hline Main Effects & 16.228 & 3 & 5.409 & 30.174 & .000 & Significant \\
\hline Treatment & 14.561 & 2 & 7.281 & 40.611 & .000 & Significant \\
\hline Variety & 1.667 & 1 & 1.667 & 9.301 & .003 & Significant \\
\hline & & & tem Girth & & & \\
\hline At twenty days & & & & & & \\
\hline Main Effects & 74.831 & 3 & 24.944 & 68.449 & .000 & Significant \\
\hline Treatment & .484 & 2 & .242 & .664 & .517 & Not Significant \\
\hline Variety & 74.374 & 1 & 74.347 & 204.019 & .000 & Significant \\
\hline At fifty days & & & & & & \\
\hline
\end{tabular}




\begin{tabular}{|c|c|c|c|c|c|c|}
\hline $\begin{array}{l}\text { Main Effects } \\
\text { Treatment } \\
\text { Variety }\end{array}$ & $\begin{array}{c}108.472 \\
5.431 \\
103.441\end{array}$ & $\begin{array}{l}3 \\
2 \\
1\end{array}$ & $\begin{array}{c}36.157 \\
2.715 \\
103.041 \\
\end{array}$ & $\begin{array}{c}68.892 \\
5.174 \\
196.328 \\
\end{array}$ & $\begin{array}{l}.000 \\
.008 \\
.000\end{array}$ & $\begin{array}{l}\text { Significant } \\
\text { Significant } \\
\text { Significant }\end{array}$ \\
\hline $\begin{array}{c}\text { At eighty days } \\
\text { Main Effects } \\
\text { Treatment } \\
\text { Variety }\end{array}$ & $\begin{array}{c}111.027 \\
13.683 \\
97.344\end{array}$ & $\begin{array}{l}3 \\
2 \\
1\end{array}$ & $\begin{array}{c}37.009 \\
6.841 \\
97.344 \\
\end{array}$ & $\begin{array}{r}10.366 \\
13.008 \\
185.081\end{array}$ & $\begin{array}{l}.000 \\
.000 \\
.000\end{array}$ & $\begin{array}{l}\text { Significant } \\
\text { Significant } \\
\text { Significant }\end{array}$ \\
\hline 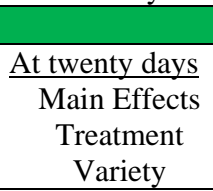 & $\begin{array}{c}29.400 \\
9.800 \\
19.600 \\
\end{array}$ & $\begin{array}{l}3 \\
2 \\
1\end{array}$ & $\begin{array}{c}9.800 \\
4.900 \\
19.600 \\
\end{array}$ & $\begin{array}{l}2.550 \\
1.275 \\
5.100 \\
\end{array}$ & $\begin{array}{l}.061 \\
.285 \\
.027\end{array}$ & $\begin{array}{c}\text { Not Significant } \\
\text { Not Significant } \\
\text { Significant }\end{array}$ \\
\hline $\begin{array}{c}\text { At fifty days } \\
\text { Main Effects } \\
\text { Treatment } \\
\text { Variety }\end{array}$ & $\begin{array}{l}313.414 \\
131.400 \\
182.044\end{array}$ & $\begin{array}{l}3 \\
2 \\
1\end{array}$ & $\begin{array}{c}104.481 \\
65.700 \\
182.044\end{array}$ & $\begin{array}{l}29.451 \\
18.519 \\
51.315\end{array}$ & $\begin{array}{l}.000 \\
.000 \\
.000\end{array}$ & $\begin{array}{l}\text { Significant } \\
\text { Significant } \\
\text { Significant }\end{array}$ \\
\hline $\begin{array}{c}\text { At eighty days } \\
\text { Main Effects } \\
\text { Treatment } \\
\text { Variety }\end{array}$ & $\begin{array}{l}59.033 \\
34.489 \\
24.544\end{array}$ & $\begin{array}{l}3 \\
2 \\
1\end{array}$ & $\begin{array}{l}19.678 \\
17.244 \\
24.544\end{array}$ & $\begin{array}{c}9.056 \\
7.936 \\
11.295\end{array}$ & $\begin{array}{l}.000 \\
.001 \\
.001\end{array}$ & $\begin{array}{l}\text { Significant } \\
\text { Significant } \\
\text { Significant }\end{array}$ \\
\hline \multicolumn{7}{|c|}{ d. Number of Shoots } \\
\hline $\begin{array}{c}\text { At twenty days } \\
\text { Main Effects } \\
\text { Treatment } \\
\text { Variety }\end{array}$ & $\begin{array}{c}70.285 \\
5.400 \\
64.861\end{array}$ & $\begin{array}{l}3 \\
2 \\
1\end{array}$ & $\begin{array}{c}23.428 \\
2.700 \\
64.861 \\
\end{array}$ & $\begin{array}{c}20.010 \\
2.306 \\
55.397\end{array}$ & $\begin{array}{l}.000 \\
.106 \\
.000\end{array}$ & $\begin{array}{l}\text { Significant } \\
\text { Not Significant } \\
\text { Significant }\end{array}$ \\
\hline $\begin{array}{c}\text { At fifty days } \\
\text { Main Effects } \\
\text { Treatment } \\
\text { Variety }\end{array}$ & $\begin{array}{c}117.222 \\
1.622 \\
115.600\end{array}$ & $\begin{array}{l}3 \\
2 \\
1\end{array}$ & $\begin{array}{c}39.074 \\
.811 \\
115.600\end{array}$ & $\begin{array}{c}36.042 \\
.748 \\
106.630\end{array}$ & $\begin{array}{l}.000 \\
.046 \\
.000\end{array}$ & $\begin{array}{l}\text { Significant } \\
\text { Not Significant } \\
\text { Significant }\end{array}$ \\
\hline $\begin{array}{c}\text { At eighty days } \\
\text { Main Effects } \\
\text { Treatment } \\
\text { Variety }\end{array}$ & $\begin{array}{c}29.422 \\
3.822 \\
25.600\end{array}$ & $\begin{array}{l}3 \\
2 \\
1\end{array}$ & $\begin{array}{c}9.807 \\
1.911 \\
25.600\end{array}$ & $\begin{array}{l}9.550 \\
1.861 \\
24.927\end{array}$ & $\begin{array}{l}.000 \\
.162 \\
.000\end{array}$ & $\begin{array}{l}\text { Significant } \\
\text { Not Significant } \\
\text { Significant }\end{array}$ \\
\hline \multicolumn{7}{|c|}{ e. Size of Leaves (width) } \\
\hline $\begin{array}{l}\text { Main Effects } \\
\text { Treatment } \\
\text { Variety }\end{array}$ & $\begin{array}{l}12.378 \\
5.806 \\
6.572\end{array}$ & $\begin{array}{l}3 \\
2 \\
1\end{array}$ & $\begin{array}{l}4.126 \\
2.903 \\
6.572\end{array}$ & $\begin{array}{l}5.357 \\
3.769 \\
8.533\end{array}$ & $\begin{array}{l}.002 \\
.027 \\
.004\end{array}$ & $\begin{array}{l}\text { Significant } \\
\text { Significant } \\
\text { Significant }\end{array}$ \\
\hline \multicolumn{7}{|c|}{ f. Size of Leaves (length) } \\
\hline $\begin{array}{l}\text { Main Effects } \\
\text { Treatment } \\
\text { Variety }\end{array}$ & $\begin{array}{c}23.036 \\
17.804 \\
5.232\end{array}$ & $\begin{array}{l}3 \\
2 \\
1\end{array}$ & $\begin{array}{l}7.679 \\
8.902 \\
5.232 \\
\end{array}$ & $\begin{array}{l}3.312 \\
3.840 \\
2.257\end{array}$ & $\begin{array}{l}.024 \\
.025 \\
.137\end{array}$ & $\begin{array}{c}\text { Significant } \\
\text { Significant } \\
\text { Not Significant }\end{array}$ \\
\hline
\end{tabular}

\section{Flowering Performance}

\section{Number of Flower Clusters}

Euphorbia Orchid showed to have more flower clusters when fertilized with carabao manure, during the different stages of observation. However, it can be noted that a slight increase was noted in Siam Ruby when fertilized with chicken manure on the $80^{\text {th }}$ day of observation. This result conforms with the work of Brady (1996) that organic fertilizer like chicken and carabao manure have long lasting contribution to plants as potash are 
slowly released in time for its flower initiation. As to treatment variable, the two other stages proved to be significantly different except for the $50^{\text {th }}$ day observation. Moreover, as to variety variable, it showed that except for the $20^{\text {th }}$ day observation, varietal difference was evident during the last two measuring periods.

\section{Number of Flowers per Cluster}

Siam Ruby produced more number of flowers per clusters, when fertilized with chicken manure during the $20^{\text {th }}$ and $50^{\text {th }}$ day observations. However, it increased during the $80^{\text {th }}$ observation when fertilized with carabao manure. In terms of treatment available, all observation stages proved to be not significant. With reference to variety, it depicts that the three-stages show significant difference.

\section{Size of Flowers}

Euphorbia Orchid showed to have bigger size of flowers when fertilized with carabao manure. Both treatment and variety variables revealed significant differences.

\section{Diameter of Flower Bracts}

Although Euphorbia orchid showed wider diameter of flower bracts when fertilized with carabao manure, it did not differ significantly with Siam Ruby.

\section{Analysis of Variance on the Flowering Parameters at Different Stages}

\begin{tabular}{|c|c|c|c|c|c|c|}
\hline Source of Variation & $\begin{array}{l}\text { Sum of } \\
\text { Squares }\end{array}$ & $\mathrm{df}$ & $\begin{array}{l}\text { Mean } \\
\text { Square }\end{array}$ & $\mathrm{F}$ & $\mathrm{p}$ & Interpretation \\
\hline \multicolumn{7}{|c|}{ a. Number of Flower Clusters } \\
\hline \multicolumn{7}{|l|}{ At twenty days } \\
\hline Main Effects & 12.822 & 3 & 4.274 & 6.306 & .001 & Significant \\
\hline Treatment & 12.422 & 2 & 6.211 & 9.164 & .000 & Significant \\
\hline Variety & .400 & 1 & .400 & .590 & .445 & Not Significant \\
\hline \multicolumn{7}{|l|}{ At fifty days } \\
\hline Main Effects & 88.111 & 3 & 29.370 & 6.690 & .000 & Significant \\
\hline Treatment & 58.067 & 2 & 29.033 & 6.613 & .002 & Significant \\
\hline Variety & 30.044 & 1 & 30.044 & 6.43 & .000 & Significant \\
\hline \multicolumn{7}{|l|}{ At eighty days } \\
\hline Main Effects & 297.967 & 3 & 99.322 & 30.000 & .000 & Significant \\
\hline Treatment & 184.622 & 2 & 92.311 & 27.919 & .000 & Significant \\
\hline Variety & 113.344 & 1 & 113.344 & 34.281 & .003 & Significant \\
\hline \multicolumn{7}{|c|}{ b. Number of Flowers per Cluster } \\
\hline \multicolumn{7}{|l|}{ At twenty days } \\
\hline Main Effects & 962.467 & 3 & 320.822 & 17.689 & .000 & Significant \\
\hline Treatment & 78.867 & 2 & 39.433 & 2.174 & .120 & Not Significant \\
\hline Variety & 883.600 & 1 & 883.600 & 48.719 & .000 & Significant \\
\hline$\frac{\text { At fifty days }}{\text { Main Fffects }}$ & 110911 & & 130027 & 15148 & 000 & cont \\
\hline
\end{tabular}




\begin{tabular}{|c|c|c|c|c|c|c|}
\hline $\begin{array}{c}\text { Treatment } \\
\text { Variety }\end{array}$ & $\begin{array}{c}55.800 \\
364.011\end{array}$ & $\begin{array}{l}2 \\
1\end{array}$ & $\begin{array}{c}27.900 \\
364.011\end{array}$ & $\begin{array}{c}3.020 \\
39.403\end{array}$ & $\begin{array}{l}.054 \\
.000\end{array}$ & $\begin{array}{c}\text { Not Significant } \\
\text { Significant }\end{array}$ \\
\hline $\begin{array}{c}\text { At eighty days } \\
\text { Main Effects } \\
\text { Treatment } \\
\text { Variety }\end{array}$ & $\begin{array}{c}538.222 \\
5.422 \\
532.900\end{array}$ & $\begin{array}{l}3 \\
2 \\
1\end{array}$ & $\begin{array}{c}179.441 \\
2.711 \\
532.900\end{array}$ & $\begin{array}{c}9.125 \\
.138 \\
27.099\end{array}$ & $\begin{array}{l}.000 \\
.871 \\
.000 \\
\end{array}$ & $\begin{array}{c}\text { Significant } \\
\text { Not Significant } \\
\text { Significant }\end{array}$ \\
\hline \multicolumn{7}{|c|}{ c. Size of Flowers } \\
\hline $\begin{array}{l}\text { Main Effects } \\
\text { Treatment } \\
\text { Variety }\end{array}$ & $\begin{array}{c}103.311 \\
29.935 \\
66.439\end{array}$ & $\begin{array}{l}3 \\
2 \\
1\end{array}$ & $\begin{array}{l}34.437 \\
14.967 \\
66.439\end{array}$ & $\begin{array}{c}55.193 \\
23.989 \\
106.484\end{array}$ & $\begin{array}{l}.000 \\
.000 \\
.000\end{array}$ & $\begin{array}{l}\text { Significant } \\
\text { Significant } \\
\text { Significant }\end{array}$ \\
\hline \multicolumn{7}{|c|}{ d. Diameter of Flower Bracts } \\
\hline $\begin{array}{l}\text { Main Effects } \\
\text { Treatment } \\
\text { Variety }\end{array}$ & $\begin{array}{l}5.984 \\
1.495 \\
4.489\end{array}$ & $\begin{array}{l}3 \\
2 \\
1\end{array}$ & $\begin{array}{l}1.995 \\
.747 \\
4.489\end{array}$ & $\begin{array}{c}1.370 \\
.513 \\
3.083\end{array}$ & $\begin{array}{l}.258 \\
.600 \\
.083\end{array}$ & $\begin{array}{l}\text { Not Significant } \\
\text { Not Significant } \\
\text { Not Significant }\end{array}$ \\
\hline
\end{tabular}

\section{Conclusion}

The use of organic fertilizers like the use of animal dungs or wastes was proven effective based on the different trials made. The growth performance of Euphorbia fulgens was attributed the use of the carabao manure as a form of an organic fertilizer. As to growth parameters, carabao manure yielded more number of leaves and shoots and taller Euphorbia Orchids. It also produced bigger stem girth, wider and longer leaf sizes of Siam Ruby hybrid. As to flowering parameters, carabao manure influenced the growth of more number of flower clusters and bigger sizes of flowers of Euphorbia Orchid. On the other hand, chicken manure also influenced the growth of more number of flowers per cluster of Siam Ruby during the $50^{\text {th }}$ day observation and carabao manure during the $20^{\text {th }}$ day observation.

\section{Recommendations}

Based on the findings and conclusions of the study, the following recommendations are given that: (1) school managers should consider the findings of this study as a guide in planning and designing horticulture-based instructional material, (2) agriculture and technology instructors and professors should use the findings of the study as reference and the enrichment of resource units, course guides and syllabi, (3) technology students, professors, module writers and school managers should consider the utilization of the results of the study in instruction and other curriculumrelated tasks, (4) extension workers may help disseminate this technology to local ornamental growers, pot flowering plant collectors, housewives and out-of-school youths in order to improve Euphorbia production and thus increase their income, and (5) another study in areas similar to the climatic condition of Eastern Samar State University-Salcedo campus using the same test plants with chicken manure and carabao in varied quantity, be conducted to further validate the results of this study. 


\section{References:}

Bautista, O. et al. (1994). Introduction to tropical horticulture. Laguna: University of the Philippines

Brady, N. (1996). The nature and properties of soils. New York: McMillan Publishing House

Carbonell, S. (2015). Correlates of queen pineapple (Ananascomosus Linn) farming practices in Camarines Norte, Philippines. Asia Pacific Journal of Multidisciplinary Research, Volume 3, No. 5.

Catuday, A.D. (1985). Yield response of sweet potato as influenced by different planting positions, Eastern Samar State College-Borongan, Eastern Samar, BSA. Unpublished Thesis,

Carola,? (2009). Growing adenium from seed... Date Retrieved May 20, 2016 http:// www.tropicanursery.com/adenium/commercial.html

Farina, L. (1993). Experimental research on timing euphorbia (euphorbia fulgens karw.) for cut flowers production) Date Retrieved May 20, 2016 http://agris.fao.org/agris-search/search.do?recordID=XE8461096

Gomez, K. \& Gomez A. (1984). Statistical procedures for agricultural research. $2^{\text {nd }}$ Ed., Canada: John Miley \& Sons, Inc.

Inocian, R. and Nuñeza, L. (2015). The "gulayan sa paaralan" (school vegetable garden) in

response to sustainable development. European Scientific Journal, Volume 11, No. 8, March 2015 Edition.

Interflora, (n.d.). Euphorbia fulgens. Flowers and Plants Date Retrieved May 20, 2016 http://www.flowers.org.uk/flowers/flowers-names/e-h/euphorbiafulgens/

Kone, B. et al, (2014). Organic and mineral fertilization of oil palm at the nursery stage. European Scientific Journal, Volume 10, No. 24, August 2014 Edition.

Lantican, R. (2001). The science and practice of crop production, Los Banos, Laguna: SEAMAO SEARCA \& UPLB

Larson, R.A. (1992). Introduction to floriculture. 2nd Ed. New York. Academic Press Inc.

PCARRD (1983). Philippine recommend for vegetable crops. Los Banos, Laguna

PhilRice (2002). Integrated nutrient management. Nueva Ecija: Philippine Rice Research Institute

Railey, E. \& Shry, C. Jr. (1997). Introductory horticulture. Albany: Delmar Publisher

Runger, W. and Albert, G. (1975). Influence of temperature, soil moisture and CCC on the flowering of euphorbia fulgens. Date Retrieved May 20, 2016 
http://www.researgate.net/publication/248476324_Influence_of_temperature _soil_moisture_and

_CCC_on_the_flowering_of_Euphorbia_fulgen

Sarian, S. (2004). How to make money in ornamental plants. Agricultural Magazine. Manila: Manila Bulletin Publication Corp. 